Justus E. E. van Beusekom

\title{
A historic perspective on Wadden Sea eutrophication
}

\begin{abstract}
In this paper, a reconstruction of the preindustrial trophic status of the Wadden Sea is presented. A conceptual model is outlined that links the organic matter and nutrient dynamics in the Wadden Sea with riverine nutrient input. Fundamental processes in this model are: a nutrient-limited offshore primary production and the subsequent import of primary produced organic matter from the North Sea into the Wadden Sea. Two approaches have been followed to estimate the production and remineralisation levels under preindustrial conditions. The first approach is based on present-day relationships between the seasonal cycle of $\mathrm{NH}_{4}$ and $\mathrm{NO}_{2}$ in the western Dutch Wadden Sea and suggests, on average, sixfold lower production and remineralisation rates under pre-industrial conditions (range: four to eight times). The second approach is based on present carbon budgets extrapolated to preindustrial budgets on the basis of present relationships between winter nutrient concentrations, annual primary production and annual organic matter turnover rates, and suggests a fivefold lower organic matter turnover under pre-industrial conditions (annual primary production: $\sim 55 \mathrm{~g} \mathrm{C} \mathrm{m}^{-2}$ year $^{-1}$, annual remineralisation: $\sim 77 \mathrm{~g} \mathrm{C} \mathrm{m}^{-2}$ year $^{-1}$ ). Better pre-industrial light conditions in the Wadden Sea may have allowed a more efficient use of nutrients, a higher annual primary production of about $86 \mathrm{~g} \mathrm{C} \mathrm{m}^{-2}$ year $^{-1}$ and annual remineralisation rates of about $108 \mathrm{~g} \mathrm{C} \mathrm{m}^{-2}$ year $^{-1}$.
\end{abstract}

Keywords Eutrophication Pre-industrial · Wadden Sea $\cdot$ Nutrients $\cdot$ Organic matter budgets

Communicated by H.K. Lotze and K.Reise

J. E. E. van Beusekom ( $\square)$

Alfred-Wegener-Institute for Polar and Marine Research,

Wadden Sea Station Sylt, Hafenstrasse 43,

25992 List/Sylt, Germany

E-mail: jbeusekom@awi-bremerhaven.de

Tel.: + 49-4651-956-151

\section{Introduction}

Eutrophication has been recognised as a global problem (Nixon 1990). Among the driving factors are an increasing human population, domestic sewage, the use of artificial fertilisers, animal production, deforestation and atmospheric input from combustion of fossil fuels (e.g. Nixon 1995; Billén and Garnier 1997). Consequences of increased eutrophication are increased primary production and remineralisation, increased turbidity, proliferation of opportunistic macroalgae, anoxia, seagrass decline and changes in the benthic and pelagic community (e.g. Cloern 2001). All of the abovementioned consequences of coastal eutrophication have been observed in the Wadden Sea, a shallow, tidally influenced area in the southeastern North Sea fringing the Dutch, German and Danish coasts (de Jonge and de Jong 1992; de Jonge et al. 1993; Reise 1994; van Beusekom et al. 2001; Cadée and Hegeman 2002). Notable changes have included the proliferation of Phaeocystis and an increase in pelagic primary production since the end of the 1970s (Cadée and Hegeman 2002) and the proliferation of green macroalgae during the early 1990s (Reise and Siebert 1994). Due to the increased phytoplankton biomass in the western Dutch Wadden Sea, macrobenthic biomass has increased, but this relationship is not clear for other parts of the Wadden Sea (de Jonge et al. 1993; van Beusekom et al. 2001).

To properly assess the present state of the environment, a thorough understanding of its natural state and variability is needed. In most cases, such knowledge is not available. This holds true for changes in the nutrient status of the Wadden Sea. Most reliable biogeochemical observations from this area date from the past three to four decades. A reconstruction of the preindustrial trophic status of the Wadden Sea can therefore only be based on extrapolating present knowledge of the influence of natural processes and human impact on nutrient and organic matter dynamics in the 
Wadden Sea. In this contribution, estimates of preindustrial annual production and remineralisation rates for two Wadden Sea settings, with high and with low riverine influence, are presented. The western Dutch Wadden Sea will be used as a model for the Wadden Sea with a high riverine influence, the Sylt-Rømø Bight as a model for the Wadden Sea with a low riverine influence. First, a short overview of recent trends in Wadden Sea eutrophication is given. Next, a conceptual model linking riverine nutrient input and primary production in the coastal parts of the North Sea with particle import into and eutrophication of the Wadden Sea will be outlined. Present-day relationships between winter nutrient concentrations and annual primary production and between riverine nutrient input and organic matter turnover will be used to estimate preindustrial organic matter remineralisation and productivity levels of the Wadden Sea.

\section{Recent changes in Wadden Sea eutrophication}

During the past century, riverine nutrient discharges into the North Sea have increased, especially since the 1950s (e.g. van Bennekom and Wetsteijn 1990; de Jong et al. 1999). This increase has affected Wadden Sea nutrient cycles and productivity. During recent decades, a two- to threefold increase in phytoplankton and phytobenthos primary production has been observed throughout the entire Wadden Sea (Cadée 1984; Cadée and Hegeman 1993; de Jonge et al. 1996; Asmus et al. 1998). Phytoplankton primary production in the western Dutch Wadden Sea (Marsdiep) reached a maximum in 1994, and a decreasing trend has been observed since then (Cadée and Hegeman 2002). Based on a recent review of timeseries for the 2004 Quality Status Report of the Wadden Sea, van Beusekom et al. (unpublished data) suggest a general decrease in Wadden Sea eutrophication.

Several explanations have been put forward to relate Wadden Sea eutrophication with an enhanced nutrient loading. De Jonge (1990) found a significant correlation between changes in mean annual chlorophyll $\mathrm{a}$ in the Marsdiep area and annual primary production (pre1987) with the dissolved inorganic phosphate load from the IJsselmeer into the Marsdiep area and not with other nutrient components or sources. Based on more recent primary production data, Cadée and Hegeman (1993) showed that, despite decreasing phosphate loads, primary production in the Wadden Sea remained high. They observed a good correlation between annual primary production and annual Rhine discharge and suggested that the nitrogen load of the river Rhine kept the phytoplankton production in the Dutch coastal zone at a high level, despite decreasing phosphorus discharges. The productivity of the Wadden Sea has more recently been reanalysed by de Jonge et al. (1996) and the importance of increased phosphorus input through the
Dover Channel was stressed. They showed that, despite the decreasing riverine loads in phosphorus, this element still might play a significant role in fuelling the primary production in the western Dutch Wadden Sea. However, the increased productivity of the Wadden Sea is not only a direct effect of nutrient-rich river water being advected into the area but also, and perhaps even mainly, an indirect effect due to an increased import and remineralisation of organic matter from the adjacent coastal zone (Postma 1954; de Jonge and Postma 1974; van Beusekom et al. 1999). Changes in the seasonal cycle of nutrients might be used as a direct indicator of changes in organic matter import and remineralisation rates. De Jonge and Postma (1974) already explored this strategy and inferred a tripling of the organic matter import from the North Sea into the Wadden Sea from 1950 to 1971-1972. On the other hand, Helder (1974) did not observe any clear-cut change in the annual nitrogen cycle between 1960-1962 and 1971-1972 in the Dutch Wadden Sea. Van Beusekom et al. (2001) and van Beusekom and de Jonge (2002) linked the shape of seasonal cycles of ammonium and nitrite to the eutrophication status of the Wadden Sea. They inferred a two- to threefold increase in the eutrophication status of the western Dutch Wadden Sea since the earliest measurements of nitrogen compounds in 1960-1962 (Postma 1966).

\section{Conceptual model of Wadden Sea eutrophication}

Three aspects characterise Wadden Sea eutrophication. Firstly, the Wadden Sea imports organic matter from the North Sea (Postma 1954; van Beusekom et al. 1999). Secondly, the nutrient and organic matter dynamics in the Wadden Sea have responded to an increased organic matter import (de Jonge and Postma 1974; van Beusekom and de Jonge 2002). Thirdly, pelagic primary production and phytoplankton biomass in the Wadden Sea respond to nutrient input (Cadée and Hegeman 1993). After maximum values during the 1980s and 1990s, riverine nutrient input and Wadden Sea phytoplankton biomass and primary production now show a decreasing trend (Cadée and Hegeman 2002).

These processes have been summarised in a conceptual model that links riverine nutrient input with the nutrient and organic matter dynamics of the Wadden Sea (Fig. 1, adapted from van Beusekom and de Jonge 2002): nutrients are imported into the North Sea via rivers and from the Atlantic Ocean. In the North Sea, nutrients enable a certain amount of primary production. Part of this primary produced organic matter in the North Sea is imported into the Wadden Sea. Within the Wadden Sea, primary production is supported by nutrient release from remineralised organic matter. The above conceptual model is discussed in detail elsewhere (van Beusekom and de Jonge 2002). 
Statistical analysis of influence of riverine total nitrogen loads on organic matter remineralisation in the Dutch Wadden Sea

Based on the above conceptual model, van Beusekom and de Jonge (2002) tested the hypothesis that in years with high riverine nutrient loads into the North Sea more organic matter is produced in the open North Sea and more organic matter is imported and remineralised in the Wadden Sea than in years with low nutrient loads. Based on monitoring data from the Dutch Wadden Sea (1978-1997) it can be shown that a significant correlation exists between total nitrogen (TN) input via the rivers Rhine and Meuse and the autumn concentrations of $\mathrm{NH}_{4}+\mathrm{NO}_{2}$ in the Dutch Wadden Sea. Autumn values were chosen because during that season phytoplankton uptake is limited by light, and nutrient concentrations rapidly increase in the water column due to ongoing remineralisation processes. $\mathrm{TN}$ input was chosen to account for all potential nitrogen sources, but it should be noted that dissolved inorganic nitrogen (DIN) accounts, on average, for $83 \%$ of TN. A multiple regression was carried out with phytoplankton biomass (chlorophyll) and temperature as co-variables for the following reasons. High phytoplankton biomass might suppress the $\mathrm{NH}_{4}+\mathrm{NO}_{2}$ concentrations due to nutrient uptake, and high temperatures might enhance the $\mathrm{NH}_{4}+\mathrm{NO}_{2}$ concentrations due to increased remineralisation rates. Van Beusekom and de Jonge (2002) found a significant multiple correlation $\left(r^{2}=0.63 ; P<0.0017\right.$; $n=19$; one outlier: 1983) explaining $\mathrm{NH}_{4}+\mathrm{NO}_{2}$ levels in autumn with a significant positive effect of riverine TN input, a significant negative effect of phytoplankton and no significant effect of temperature.

We reinvestigated the relation between $\mathrm{TN}$ input and the autumn remineralisation levels in the Dutch Wadden Sea. We also investigated whether the extrapolation of this relationship to pre-industrial TN loads gives a useful estimate of the recent increase in the trophic status of the Wadden Sea by comparing it with a pre-industrial carbon budget of the Wadden Sea.

\section{Material and methods}

\section{Area description}

The Wadden Sea is a shallow coastal sea along the Dutch, German and Danish North Sea coast. Most of the Wadden Sea is protected from the North Sea by barrier islands. The Wadden Sea is strongly influenced by tides, with tidal ranges from 1.2 to $2 \mathrm{~m}$ in the Dutch and Danish Wadden Sea, increasing to $3-3.5 \mathrm{~m}$ in the central Wadden Sea near the Elbe and Weser estuaries (Fig. 2). Twice daily about $50 \%$ of the Wadden Sea emerges during low tide. These tidal flats consist mostly of sand. The Dutch Wadden Sea can be divided into a western and an eastern part. The western Dutch Wad- den Sea is strongly influenced by the river Rhine in two ways. Firstly, a mixture of Rhine water and coastal water is advected via the tidal inlet into the Wadden Sea. Secondly, the river IJssel - a branch of the Rhine - carries fresh water via the IJsselmeer directly into the Wadden Sea. Both sources transport similar amounts of freshwater into the western Dutch Wadden Sea (IJsselmeer: $60 \%$, North Sea coastal water: $40 \%$; Zimmerman 1976). Long-term average salinity (DONAR Database, Rijkswaterstaat, the Netherlands) increases from 21 in January to 28 in summer. Salinities in the eastern Dutch Wadden Sea are about $10-30 \%$ higher (27 in January, about 30 in summer). In contrast to the Dutch Wadden Sea, nutrient dynamics of the present Sylt-Rømø Bight are dominated by exchange processes with the North Sea (Gätje and Reise 1998). Long-term monthly salinities (1973-2003) in the Sylt-Rømø Bight are between 27-28 in February and 31 in August.

\section{Data}

The data used in this study were derived from the DONAR database of the Dutch Monitoring Programme. Riverine (1977-2002) input data are based on monitoring data for the two main discharge points of the rivers Rhine and Meuse at Massluis and Haringvlietsluis. The data were extrapolated by Lenhart and Pätsch (2001) to daily loads and updated with newer data from the Dutch Monitoring Database (http://www.waterbase.nl). A map of the Wadden Sea with the above-mentioned sampling stations is shown in Fig. 2.

\section{Results}

Influence of riverine TN loads on organic matter remineralisation in the Dutch Wadden Sea: an update

The influence of riverine TN load on the $\mathrm{NH}_{4}$ and $\mathrm{NO}_{2}$ cycle in the western Dutch Wadden Sea mentioned in the Introduction was reanalysed with additional data (19982002). The dependent factor is the mean of monthly mean $\mathrm{NH}_{4}+\mathrm{NO}_{2}$ concentrations in the western Dutch Wadden Sea from September until November. The independent factor is the total TN load of the rivers Rhine and Meuse during the previous 9 months (December-August). The statistical analysis shows that TN input into the North Sea before and during the phytoplankton growth season has a significant influence on the amount of nitrogen released into the Wadden Sea during the autumn after the growth season. Almost 50\% of the interannual $\left[\mathrm{NH}_{4}+\mathrm{NO}_{2}\right]$-variability in the western Wadden Sea is explained by the riverine TN load (Table 1). In contrast to the former analysis, only the riverine TN load has a significant effect. The linear relationship between riverine $\mathrm{TN}$ input and the mean concentration of $\mathrm{NH}_{4}$ and $\mathrm{NO}_{2}$ during autumn is shown 


\section{River}

North Sea

Wadden Sea

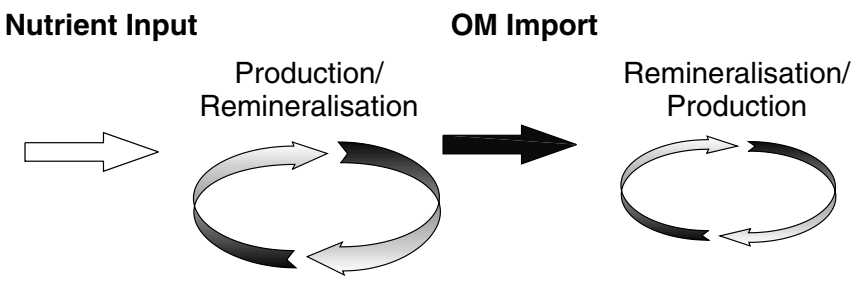

Fig. 1 Conceptual model linking riverine nutrient input with North Sea primary production, the import of part of this organic matter (OM import) into the Wadden Sea and the remineralisation and productivity of the Wadden Sea

in Fig. 3. The regression curve shown does not include one outlier (1983, $\mathrm{NH}_{4}+\mathrm{NO}_{2} \sim 32 \mu \mathrm{M}$; deviation $>2$ times the standard deviation of the regression) as outliers may have a strong influence on the regression curve.

The relationship in Fig. 3 can be used to predict background $\mathrm{NH}_{4}+\mathrm{NO}_{2}$ levels in autumn under preindustrial riverine TN loads. Laane (1992) proposed background $\mathrm{TN}$ concentrations for rivers entering the North Sea of about $45 \pm 25 \mu \mathrm{M}$. The mean TN concentration of about $340 \mu \mathrm{M}$ in the Rhine/Meuse water entering the North Sea at present (1978-2002) implies an increase in TN loads by a factor of about eight. Based on the relationship in Fig. 3, and on a mean TN Load via Rhine and Meuse for 1978-2002 of 284,000 tonnes (December-August), this implies $\mathrm{NH}_{4}+\mathrm{NO}_{2}$ levels in the western Dutch Wadden Sea of $3.6 \mu \mathrm{M}$ at background riverine $\mathrm{TN}$ loads eightfold below present. The above estimate does not take into account additional sources like atmospheric deposition. I estimated the atmospheric contribution to be $1.2 \mu \mathrm{M}$, giving a preindustrial autumn level of $2.4 \mu \mathrm{M}$. The value of $1.2 \mu \mathrm{M}$ was estimated as follows. At present the primary production fuelled by atmospheric deposition contributes about $11 \%$ of the total organic matter turnover in the Sylt-Rømø Bight (see next section). In the western Dutch Wadden Sea, where direct riverine nutrient input (via the IJsselmeer) plays a large role but the higher turbidity allows a less efficient use of these nutrients, atmospheric $\mathrm{N}$ input will probably have a less prominent impact. In the Sylt-Rømø Bight, imported organic matter is being used more efficiently (import/annual production: 0.36) than in the western Dutch Wadden Sea (import/annual production: 0.50 ). Assuming a proportionally less efficient use of organic matter produced with atmospheric nitrogen, at present $8 \%$ of the total organic matter turnover is driven by atmospheric deposition. At mean present autumn values of $14.8 \mu \mathrm{M}$ $\left(\mathrm{NH}_{4}+\mathrm{NO}_{2}\right)$, this equals $1.2 \mu \mathrm{M}$.

In Fig. 4 these values are put in perspective with present levels as observed during dry years with low riverine discharge and low TN loads, and wet years with a high riverine TN load. If we assume that the autumn levels are a good indicator of organic matter turnover, the present levels are about six times higher than under pre-industrial TN loads (range: four to eight times). Compared to the earliest $\mathrm{NH}_{4}+\mathrm{NO}_{2}$ measurements in 1960-1961 (Postma 1966), pre-industrial organic matter turnover was about 2.5 times lower and present turnover is 1.5-3 times higher (Fig. 4). Projecting these values onto a carbon budget of the western Dutch Wadden Sea (annual pelagic and benthic production $298 \mathrm{~g}$ $\mathrm{C} \mathrm{m}^{-2}$ year ${ }^{-1}$; annual pelagic and benthic remineralisation $450 \mathrm{~g} \mathrm{C} \mathrm{m}^{-2}$ year $^{-1}$; van Beusekom et al. 1999),
Fig. 2 A map of the present Wadden Sea

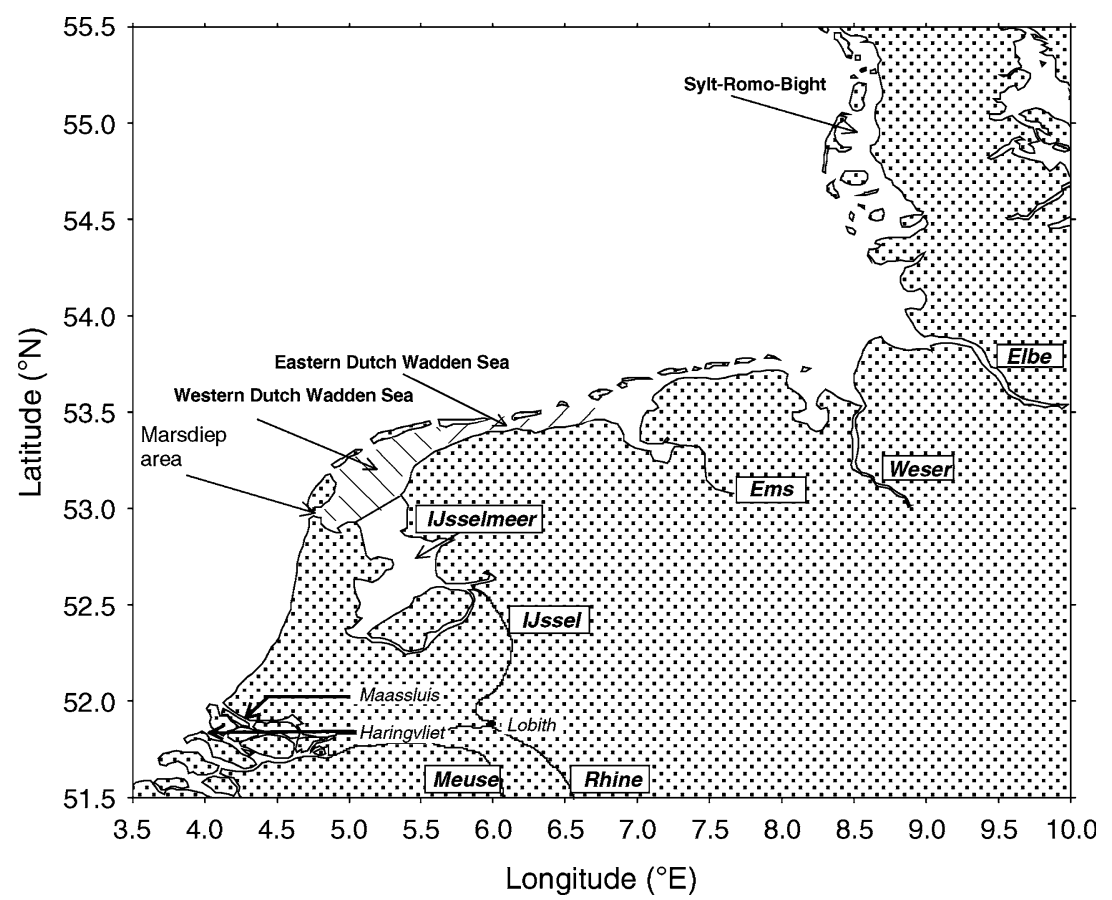




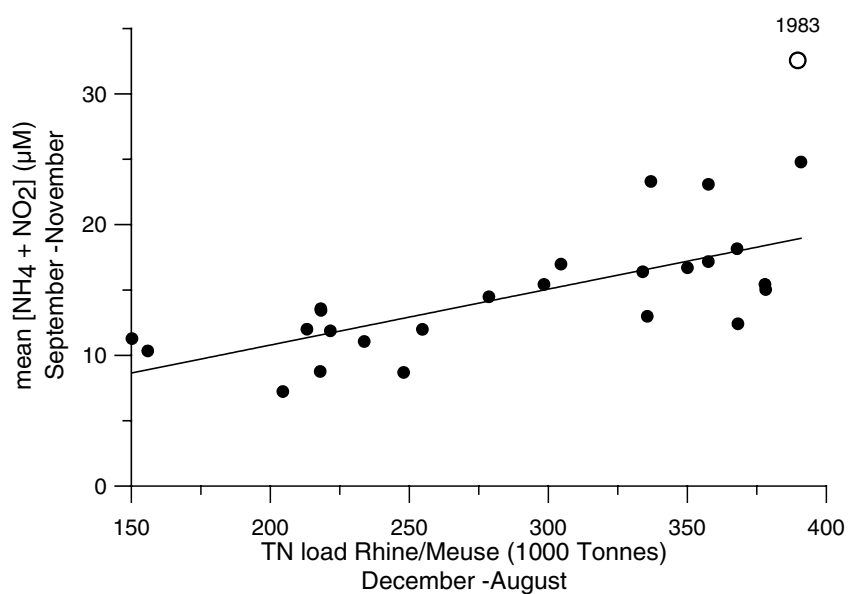

Fig. 3 Correlation between autumn values of $\mathrm{NH}_{4}+\mathrm{NO}_{2}(\mu \mathrm{M}$; mean of monthly mean from September to November, 1978-2002) in the western Dutch Wadden Sea with nutrient discharge (1,000 tonnes; December-August) of the rivers Rhine and Meuse at Maassluis and Haringvlietsluis (Fig. 2). The regression function $\left(Y=2.2+0.043 \times X ; n=24 ; r^{2}=0.51 ; P<0.00009\right)$ does not include one outlier (1983)

pre-industrial annual primary production would be $\sim 50 \mathrm{~g} \mathrm{C} \mathrm{m}^{-2}$ year $^{-1}$, and pre-industrial annual remineralisation $\sim 75 \mathrm{~g} \mathrm{C} \mathrm{m}^{-2}$ year ${ }^{-1}$. The latter includes organic matter import from sea and from riverine sources (in this case IJsselmeer).

Changes in organic matter import: a budget approach

The Wadden Sea is a heterotrophic area importing organic matter from the North Sea, a feature shared with many coastal areas (Smith and Hollibaugh 1993; Heip et al. 1995). Carbon budgets suggest that at present about $100 \mathrm{~g} \mathrm{C} \mathrm{m}^{-2}$ year ${ }^{-1}$ is imported into the Wadden Sea (van Beusekom et al. 1999). This amount will certainly have been much lower under pre-industrial nutrient conditions. First, I will discuss present relationships between winter nutrient concentrations and annual pelagic primary production in the North Sea. This relationship will be used to estimate offshore pelagic primary production and organic matter import under pre-industrial nutrient conditions. I assume that the amount of organic matter import is proportional to the offshore primary production.

Table 1 Results of the multiple regression analysis between the mean autumn concentrations of $\mathrm{NH}_{4}+\mathrm{NO}_{2}$ as the dependent variable and total nitrogen input into the North Sea via Rhine and Meuse ( $R M$, tonnes between December and August), autumn temperature $\left(T E M P,{ }^{\circ} \mathrm{C}\right)$ and autumn chlorophyll a $(C H L A, \mu \mathrm{g} / \mathrm{l})$
Present primary production in the North Sea: relationships with winter $N$ concentrations

Annual primary production levels in the North Sea range between about 70 and $500 \mathrm{~g} \mathrm{C} \mathrm{m}^{-2}$ year $^{-1}$. In general, the levels are lowest in the central North Sea and along the English east coast, where low nutrient levels prevail, and highest along the continental coast where high winter nutrients prevail (e.g. Joint and Pomroy 1993). Van Beusekom and Diel-Christiansen (1994) tentatively related the annual primary production in different parts of the North Sea (ICES boxes) with the amount of winter nitrate. For the tidally mixed coastal zone they used the entire water column, for seasonally stratified areas the upper $25 \mathrm{~m}$ (approximate depth of the seasonal thermocline). On average, the amount of nitrogen fixed by the spring bloom had to be turned over five times to explain the annual primary production. Hydes et al. (1999) compared the annual primary production in the North Sea south of $55^{\circ} \mathrm{N}$ with the annual new production based on the amount of nitrate available in March before the onset of the spring phytoplankton bloom. They included in their calculations the nitrogen load by rivers and atmosphere during the growth period. Hydes et al. (1999) calculated a fivefold annual turnover of the new production in the nitrogen-limited central North Sea as well as in the nutrient-rich Dutch and German coastal zone. Van Beusekom et al. (1999) applied a similar approach to the entire German Bight and found an annual turnover rate of three to four. In conclusion, a fourfold turnover of the new production based on winter nitrate (or nitrogen) concentrations seems to provide good estimate of the annual primary production in the coastal North Sea outside the Wadden Sea.

The term "turnover" should be used with care. It does not reflect turnover rates on the levels of organisms and on timescales of hours, as in the "microbial loop", but the ratio between the new production during the spring bloom and the annual primary production, i.e. turnover on an ecosystem scale and on the timescale of a year. The maximum value of five reflects the maximum efficiency of the North Sea. The lower values towards the coast and in the Wadden Sea suggest that, presumably because of adverse light conditions, these coastal systems make less efficient use of nutrients in terms of annual primary production of organic matter. Despite all uncertainties connected with this concept, the turnover

as independent variables. Autumn is defined as the period September-November. $B$ is the regression coefficient. Beta is a standardised regression coefficient allowing a comparison of the influence of the independent variables on the overall regression. $r=0.729 ; r^{2}=0.532 ; F_{3,21}=7.9808 ; P<0.00097$

\begin{tabular}{llllll}
\hline & Beta & Standard error beta & $B$ & Standard error $B$ & $t(21)$ \\
\hline Constant & & & -9.25 & 11.50 & -0.80 \\
RM & 0.65 & 0.156 & 0.00005 & 0.00001 & 0.429 \\
CHLA & -0.12 & 0.149 & -0.18 & 0.21 & 0.0004 \\
TEMP & 0.15 & 0.156 & 0.95 & 0.94 & -0.84 \\
\hline
\end{tabular}


values show consistent patterns with decreasing values towards the coast (Heip et al. 1995; Hydes et al. 1999; van Beusekom and de Jonge 1998; van Beusekom et al. 1999).

Pre-industrial pelagic primary production levels in the open North Sea along the Wadden Sea

With the above-mentioned relationship between winter nutrient concentrations and annual primary production, the pre-industrial annual primary production can be estimated as follows: Laane et al. (1992) deduced background TN concentrations for continental rivers (in this case the Rhine) of $45 \mu \mathrm{M}$ and for the Atlantic Water (salinity 35) entering the North Sea through the Channel of $8 \mu \mathrm{M}$. Assuming conservative mixing of $\mathrm{TN}$ and coastal water salinity outside the Wadden Sea of 30, a winter TN concentration of $13.3 \mu \mathrm{M}$ is estimated. At a mean water depth of $15 \mathrm{~m}$, this enables a new production of $199 \mathrm{mmol} \mathrm{N} \mathrm{m}^{-2}$ year $^{-1}\left(1.3 \mathrm{~mol} \mathrm{C} \mathrm{m}^{-2}\right.$ year $^{-1}$ or $15.8 \mathrm{~g} \mathrm{C} \mathrm{m}^{-2}$ year $^{-1}$ ) and an annual primary production of $5.3 \mathrm{~mol} \mathrm{C} \mathrm{m}^{-2}$ year $^{-1}\left(63 \mathrm{~g} \mathrm{C} \mathrm{m}^{-2}\right.$ year $\left.^{-1}\right)$ at a turnover rate of four. At present, the annual pelagic primary production at a salinity of 30 is about $933 \mathrm{mmol}$ $\mathrm{N} \mathrm{m}^{-2}$ year ${ }^{-1}$ (322 $\mathrm{g} \mathrm{C} \mathrm{m}^{-2}$ year $^{-1}$ ) assuming a TN river concentration of $340 \mu \mathrm{M}$ and an annual atmospheric input of about $80 \mathrm{mM} \mathrm{m}^{-2}$ year $^{-1}$ (Ærtebjerg et al. 2002). Near major freshwater sources, these values can be higher due to additional nutrient input during the growing season. The above estimate is well within the range observed along the Wadden Sea (e.g. Joint and Pomroy 1993).

The above estimates suggest that in the offshore North Sea along the Wadden Sea, where direct riverine input is low (like the northern Wadden Sea), the annual pelagic production under pre-industrial conditions is about five times lower than at present. If the import of

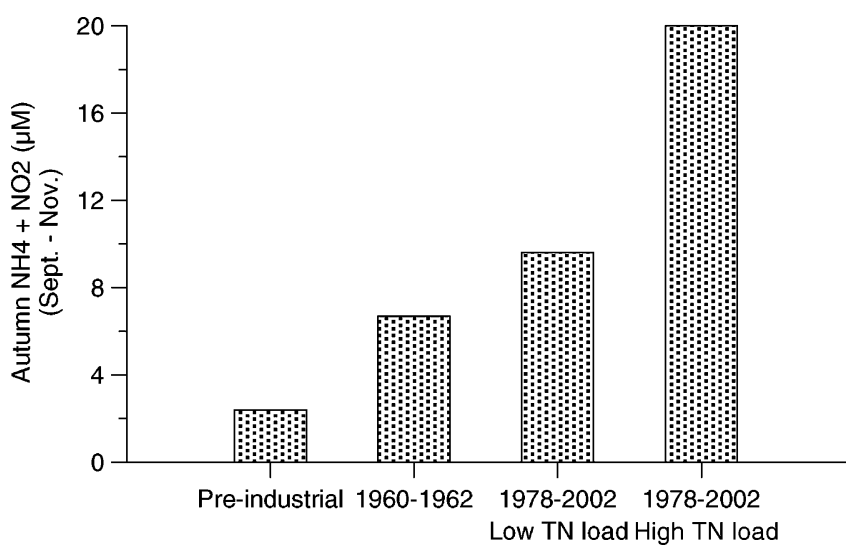

Fig. 4 Autumn values of $\mathrm{NH}_{4}+\mathrm{NO}_{2}$ in the western Dutch Wadden Sea during recent years (1978-2002) with high nutrient loads ("wet" years: 1983; 1987-1988; 1994-1995) and with low nutrient loads ("dry" years: 1990; 1996-1998; 2000) compared with the earliest measurements (1960-1962) by Postma (1966) and the present pre-industrial estimate organic matter from the North Sea to the Wadden Sea is proportional to the offshore primary production, the pre-industrial import is five times lower than at present. Given a present annual import of about $110 \mathrm{~g}$ $\mathrm{C} \mathrm{m}^{-2}$ year $^{-1}$ (van Beusekom et al. 1999) pre-industrial annual levels should be about $22 \mathrm{~g} \mathrm{C} \mathrm{m}^{-2}$ year $^{-1}$.

\section{Pre-industrial organic matter budgets in the Wadden Sea} under low riverine influence

The above estimate will be put in perspective with new production and annual turnover rates in the Wadden Sea to construct a pre-industrial organic matter budget for those parts that are not strongly influenced by riverine input like areas near the Elbe/Weser estuaries and near the Rhine/Meuse/IJssel estuary. I will use the SyltRømø Bight as a model. I will not explicitly discriminate between benthic and pelagic production and assume that available nutrients are either taken up by phytoplankton or by phytobenthos. At present, both contribute equally to the annual primary production (Asmus et al. 1998).

Despite high winter nutrient concentrations, new primary production (based on winter nutrient concentrations) in the Wadden Sea is low due to its shallow depth. Compared to the North Sea, light conditions are probably worse. This will slow down the pelagic spring bloom but not affect the total amount of new production. On the other hand, the shallow depths partly compensate for this by preventing deep mixing as found in the North Sea. Spring salinities in the Sylt-Rømø Bight are typically 28 . For pre-industrial conditions, this implies a TN concentration of about $15.4 \mu \mathrm{M}$ (excluding resuspended sediments), enabling a new production of 39 mmol N m${ }^{-2}$ year $^{-1}\left(0.25 \mathrm{~mol} \mathrm{C} \mathrm{m}^{-2}\right.$ year $^{-1} ; 3.1 \mathrm{~g}$ $\mathrm{C} \mathrm{m}^{-2}$ year $^{-1}$ ) at a mean depth of $2.5 \mathrm{~m}$. This is about $15 \%$ of the estimated amount imported from the North Sea under pre-industrial conditions.

A pre-industrial annual primary production of $55 \mathrm{~g}$ $\mathrm{C} \mathrm{m}^{-2}$ year $^{-1}$ and an annual remineralisation of $77 \mathrm{~g}$ $\mathrm{C} \mathrm{m}^{-2}$ year $^{-1}$ are estimated as follows from the abovementioned new production and organic matter import (see also Table 2). At present, turnover rates for the Wadden Sea are lower than in the North Sea: about two to three (van Beusekom and de Jonge 1998; van Beusekom et al. 1999). For the Sylt-Rømø Bight these rates are 2.2 [annual primary production: $309 \mathrm{~g} \mathrm{C} \mathrm{m}^{-2}$ year $^{-1}$ (based on Asmus et al. 1998); annual import: $110 \mathrm{~g}$ $\mathrm{C} \mathrm{m}^{-2}$ year $^{-1}$ (van Beusekom et al. 1999), new production: $27.9 \mathrm{~g} \mathrm{C} \mathrm{m}^{-2}$ year $^{-1}$, based on a calculated $\mathrm{TN}$ concentration of $76.4 \mu \mathrm{M}$; new production of $6.4 \mathrm{~g}$ $\mathrm{C} \mathrm{m}^{-2}$ year ${ }^{-1}$ based on an annual atmospheric $\mathrm{N}$ input in this part of the Wadden Sea of $80 \mathrm{mmol} \mathrm{\textrm {m } ^ { - 2 }}$ (Ærtebjerg et al. 2002)]. With present turnover rates of 2.2 , a pre-industrial annual organic matter import of $22 \mathrm{~g}$ $\mathrm{C} \mathrm{m}^{-2}$ year $^{-1}$ and a new production of $3.1 \mathrm{~g}$ $\mathrm{C} \mathrm{m}^{-2}$ year $^{-1}$, annual pre-industrial primary production would be about $55 \mathrm{~g} \mathrm{C} \mathrm{m}^{-2}$ year $^{-1}$ and annual preindustrial remineralisation levels about $77 \mathrm{~g}$ 
$\mathrm{C} \mathrm{m}^{-2}$ year $^{-1}$. This is about five times lower than present levels.

\section{Discussion}

Two approaches have been chosen to derive pre-industrial carbon budgets. The first is an extrapolation to preindustrial TN input levels of the present relationship between riverine TN input and the autumn values of $\mathrm{NH}_{4}+\mathrm{NO}_{2}$ as a proxy for organic matter turnover. The second one was based on a present carbon budget extrapolated to pre-industrial nutrient levels. Both approaches predict that under pre-industrial conditions about five times less organic matter is being turned over as compared to the present situation. This value is not proportional to the riverine TN loads under pre-industrial conditions, which were about eight times lower. From a conceptual point of view, this makes sense, as two sources influence the nutrient and organic matter dynamics of the Wadden Sea: riverine sources and oceanic sources. The latter has probably changed much less than the former, and explains that the overall reaction of the Wadden Sea is not proportional to the increased TN loads. Models support the theory that a reduction in riverine nutrient loads does not lead to a proportional decrease in primary production: in the Dutch coastal zone, a $50 \%$ reduction in riverine nutrient loads yields a $10-30 \%$ reduction in coastal primary production (ASMO 1997; Lenhart 1999).

Despite the good agreement of the proposed preindustrial carbon budgets, they should be regarded with care. One important factor to be considered is the underwater light climate. Colijn and Cadée (2003) applied a conceptual model by Cloern (1999) to the Wadden Sea. This model predicts at which combination of nutrient and light one or the other becomes limiting. The analysis by Colijn and Cadée (2003) suggested that most of the time most parts of the Wadden Sea are limited by light. Only during a short period in the year, mostly around July/August, could nutrients become limiting. The above authors concluded that, at least during 1990s, the effect of light climate exceeded by far the effect of nutrients. The present study does not support this view for the western Dutch Wadden Sea: the organic matter turnover (as indicated by the autumn $\mathrm{NH}_{4}+\mathrm{NO}_{2}$ values) is a function of nutrient input, and the 1990s fit into this relationship. Although the present analysis does not exclude any effect of light, nutrients do play an important role in regulating the organic matter turnover in the Wadden Sea. However, the study by Colijn and Cadée (2003) does make it clear that light is a limiting factor during a large part of the growth season. One way of bringing together both views is that light limits phytoplankton growth during most of the year, but that the final amount of primary-produced organic matter per annum is set during the last stage of the growing season (say July-August) when, according to
Colijn and Cadée (2003), nutrients and not light limit growth.

This view has important implications for the reconstruction of the pre-industrial productivity of the Wadden Sea: the two estimates presented in this contribution both extrapolate from the present situation, i.e. similar light conditions are assumed. This is certainly not the case. Suspended matter concentrations measured during the early 1950s by Postma (1954) in the Dutch Wadden Sea were about 2.5 times lower than at present (de Jonge and de Jong 1992, 2002). According to them, the present high suspended matter concentrations in the Dutch Wadden Sea are due to dredging and dumping activities in the Rhine delta. Based on the observed correlations, they calculate a background suspended matter concentration for the western Dutch Wadden Sea of 12.4 $14.8 \mathrm{mg} / \mathrm{l}$, being similar to the $15 \mathrm{mg} / 1$ observed by Postma (1954) during the 1950s. From a historic point of view, pristine riverine suspended matter loads may have been a factor of two lower than at present (Pasternack et al. 2001, cited by Syvitski 2003). Suspended matter dynamics in the Wadden Sea might also be related to the eutrophication process: higher productivity might have led to a more effective flocculation of fine suspended matter in the North Sea and a more effective accumulation of organic matter and fines in the Wadden Sea. Also, diking has certainly influenced the suspended matter dynamics: by cutting Wadden Sea salt marshes and mud flats, natural sedimentation areas within the Wadden Sea were lost and the hydrodynamic forces within the Wadden Sea were enhanced (Reise 2005), allowing higher suspended matter concentrations in the water column. Less turbid conditions in the pre-industrial Wadden Sea probably had large effects on the whole ecosystem. Of relevance for the pre-industrial carbon budgets presented above is the possibility that the system might have functioned more efficiently. At present, the average turnover is about 2.2, but this could have been higher. In fact, the compilation of carbon budgets from temperate coastal zones by Heip et al. (1995) suggests a maximum turnover of between three and four. Applying a value for the annual turnover of 3.5 to the pre-industrial carbon budget of the Sylt-Rømø Bight gives $\sim 55 \%$ higher annual primary productivity of $86 \mathrm{~g} \mathrm{C} \mathrm{m}^{-2}$ year $^{-1}$ and $\sim 25 \%$ higher remineralisation rates of $108 \mathrm{~g}$ $\mathrm{C} \mathrm{m}^{-2}$ year $^{-1}$ (Table 2). This would imply pre-industrial production and remineralisation levels in the Sylt-Rømø Bight three to four times lower than at present.

To my knowledge, the first attempt to estimate preindustrial production levels for the Wadden Sea was made by van den Hoek et al. (1979). They estimated a seagrass production (Zostera marina) of about $300 \mathrm{~g}$ $\mathrm{C} \mathrm{m}^{-2}$ year $^{-1}$ within the stands and about $30 \mathrm{~g}$ $\mathrm{C} \mathrm{m}^{-2}$ year $^{-1}$ for the entire western Dutch Wadden Sea. Phytoplankton primary production was estimated at $300 \mathrm{~g} \mathrm{C} \mathrm{m}^{-2}$ year $^{-1}$ (threefold higher than during the $1970 \mathrm{~s}$ ) and phytobenthos at $100 \mathrm{~g} \mathrm{C} \mathrm{m}^{-2}$ year $^{-1}$ (similar to during the 1970s). The high pelagic primary production was based on the better light climate before 1932 


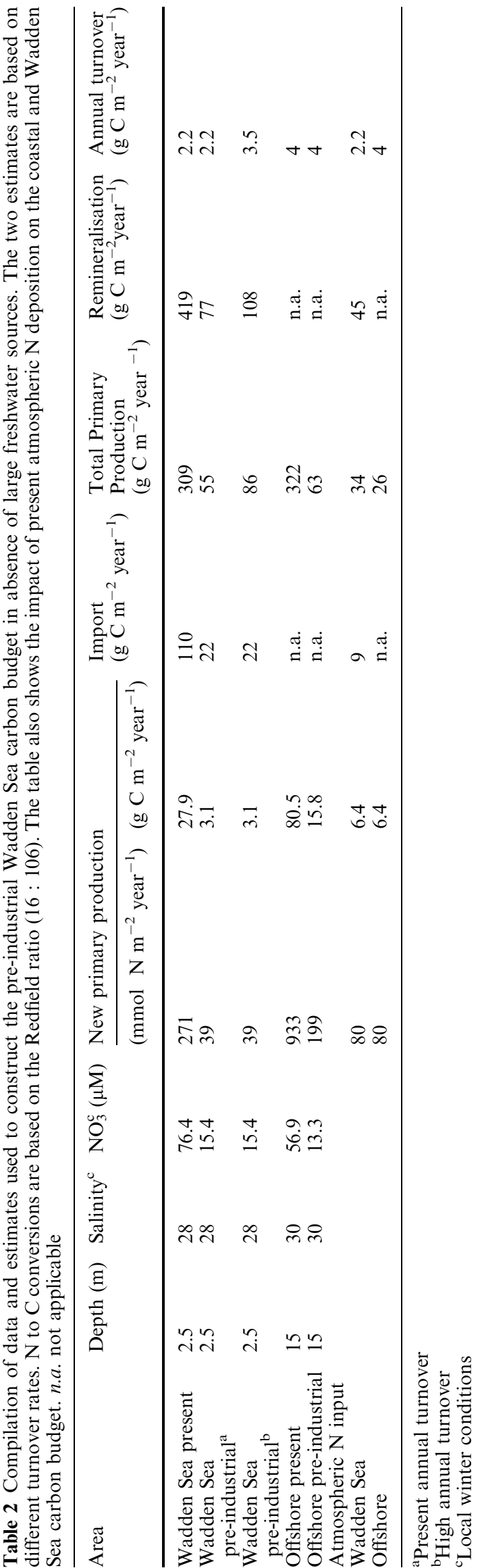

(due to the closing of the Afsluitdijk, turbidity increased in the western Dutch Wadden Sea: de Jonge and de Jong 1992). These production values are much higher than the present estimate of about $50 \mathrm{~g} \mathrm{C} \mathrm{m}^{-2}$ year ${ }^{-1}$. The main reason is that van de Hoek et al. (1979) assumed that the pelagic primary production was not nutrient- but lightlimited. Based on data collected since 1979, it is now evident that nutrients still limit Wadden Sea primary production. But the estimates by van den Hoek et al. (1979) show that, locally, primary seagrass production may have been responsible for a significant part of the pre-industrial primary production. In fact, this points to a major flaw in the present estimate. Although no explicit difference has been made between benthic and pelagic primary production, the present pre-industrial budgets were based on extrapolating from the present situation, where seagrass only plays a minor role in the organic matter budget (e.g. van den Hoek et al. 1979; Asmus et al. 1998). It may be expected that better light conditions will have prevailed in a seagrass-dominated Wadden Sea. Nutrients might have been used and might have retained more efficiently than in a seagrass-free Wadden Sea. The estimate of a total primary production of about $86 \mathrm{~g} \mathrm{C} \mathrm{m}^{-2}$ year $^{-1}$ (Table 2) for a more efficient Sylt-Rømø Bight might also be more appropriate for the western Dutch Wadden Sea.

As mentioned above, no explicit differentiation has been made in the budgets between the major primary producers. Better light conditions in the pre-industrial Wadden Sea might have favoured subtidal microphytobenthic assemblages. Although at present pelagic and benthic primary production are about equally important (van Beusekom et al. 1999), it can be speculated that benthic primary production dominated the pre-industrial Wadden Sea carbon dynamics.

Nutrient background concentrations have been calculated by van Raaphorst et al. (2000) for the Dutch Wadden Sea. Their estimate was based on nutrient background concentrations (for the year 1930) for the Dutch coastal North Sea water and for the two major freshwater sources, Rhine and IJsselmeer (van Raaphorst and de Jonge 2004), assuming conservative mixing. Their estimate of autumn DIN values $\left(\mathrm{NO}_{3}+\mathrm{NH}_{4}+\mathrm{NO}_{2} \sim 3 \mu \mathrm{M}\right)$ is higher than the present estimate $\left(\mathrm{NH}_{4}+\mathrm{NO}_{2} \sim 2.4 \mu \mathrm{M}\right)$. However, the latter estimate did not include $\mathrm{NO}_{3}$. Moreover, van Raaphorst et al. (2000) estimated background concentrations based on a conservative behaviour, whereas the present estimate aims at reflecting dynamic processes (local production of $\mathrm{NH}_{4}$ and $\mathrm{NO}_{2}$ ). During early autumn, $\mathrm{NH}_{4}+\mathrm{NO}_{2}$ concentrations and $\mathrm{NO}_{3}$ increase at present in the Sylt-Rømø Bight Sea at a ratio of 1:1, yielding a pre-industrial autumn DIN concentration of about $5 \mu \mathrm{M}$ in the absence of advective processes, or $8 \mu \mathrm{M}$ if both sources are added. Despite different approaches, the above estimates are of similar magnitude and underline the drastic increase in nutrient dynamics during the past decades, with present autumn DIN values of $\sim 30 \mu \mathrm{M}$ (van Beusekom, unpublished results). 
In the present analysis, I assumed that the annual primary production is nitrogen-limited. Although this holds for the present Wadden Sea, phosphorus might have been limiting during certain historic periods (Billén and Garnier 1997).

It is interesting to note that the present atmospheric nitrogen input is able to sustain a significant production level in the Wadden Sea (Table 2). The inputs I applied for the Sylt-Rømø Bight were based on data for the Danish North Sea coast (Ærtebjerg et al. 2002) and may have been higher in other parts of the Wadden Sea. Van Beusekom et al. (2001) used a mean value of $120 \mathrm{mM} \mathrm{m}^{-2}$ year $^{-1}$. Applying this value would increase the atmospheric deposition-driven production by $50 \%$ and yield a production level comparable to preindustrial levels.

Acknowledgements The author thanks F. Colijn, H. Lotze and an anonymous reviewer for fruitful comments. P.V.M. Bot (Rijkswaterstaat, Netherlands) provided data from the Dutch Monitoring Programme.

\section{References}

Ærtebjerg G, Andersen J, Carstensen J et al (2002) Marine områder 2001- Miljøtilstand og udvikling. NOVA-2003 Danmarks Miljøundersøgelser, 94 pp Faglig rapport fra DMU nr. 419

ASMO (1997) Modeling workshop on eutrophication Issues. 5-8 November 1996, Rijkswaterstaat, Den Haag (NL), RIKZ Report

Asmus R, Jensen MH, Murphy D, Doerffer R (1998) Primärproduktion von Mikrophytobenthos, Phytoplankton und jährlicher Biomasseertrag des Makrophytobenthos im SyltRømø Wattenmeer. In: Gätje C, Reise K (eds) Ökosystem Wattenmeer: Austausch, Transport und Stoffumwandlungsprozesse. Springer, Berlin Heidelberg New York, pp 367-392

Billén G, Garnier J (1997) The Phison River plume: coastal eutrophication in response to changes in land use and water management in the water shed. Aquat Microb Ecol 13:3-17

Cadée GC (1984) Has input of organic matter into the western part of the Dutch Wadden Sea increased during the last decades? Neth Inst Sea Res Pub Ser 10:71-82

Cadée GC, Hegeman J (1993) Persisting high levels of primary production at declining phosphate concentrations in the Dutch coastal area (Marsdiep). Neth J Sea Res 31:147-152

Cadée GC, Hegeman J (2002) Phytoplankton in the Marsdiep at the end of the 20th century; 30 years monitoring biomass, primary production and Phaeocystis blooms. J Sea Res 48:97-110

Cloern JE (1999) The relative importance of light and nutrient limitation of phytoplankton growth: a simple index of coastal ecosystem sensitivity to nutrient enrichment. Aquat Ecol 33:315

Cloern JE (2001) Our evolving conceptual model of the coastal eutrophication problem. Mar Ecol Prog Ser 210:223-253

Colijn F, Cadée GC (2003) Is phytoplankton growth in the Wadden Sea light or nitrogen limited? J Sea Res 49:83-93

de Jonge VN (1990) Response of the Dutch Wadden Sea ecosystem to phosphorus discharges from the River Rhine. Hydrobiologia 195:49-62

de Jonge VN, de Jong DJ (1992) Role of tide, light and fisheries in the decline of Zostera marina L. in the Dutch Wadden Sea Neth. J Sea Res Pub Ser 20:161-176

de Jonge VN, de Jong DJ (2002) 'Global Change' impact of interannual variation in water discharge as a driving factor to dredging and spoil disposal in the river Rhine system and of turbidity in the Wadden Sea. Estuar Coast Shelf Sci 55:969-991 de Jonge VN, Postma H (1974) Phosphorus compounds in the Dutch Wadden Sea. Neth J Sea Res 8:139-153

de Jonge VN, Essink K, Boddeke R (1993) The Dutch Wadden Sea: a changed ecosystem. Hydrobiologia 265:45-71

de Jonge VN, Bakker JF, van Stralen M (1996) Recent changes in the contributions of River Rhine and North Sea to the eutrophication of the western Dutch Wadden Sea. Neth J Aquat Ecol 30:27-39

de Jong F, Bakker JF, van Berkel CJM, Dankers NMJA, Dahl K, Gätje C, Marencic H, Potel P (1999) 1999 Wadden Sea Quality Status Report. Wadden Sea Ecosystem No. 9. Common Wadden Sea Secretariat, Trilateral Monitoring and Assessment Group, Quality Status Report Group, Wilhelmshaven

Gätje C, Reise K (1998) Okosystem Wattenmeer: Austausch, Transport und Stoffumwandlungsprozesse. Springer, Berlin Heidelberg New York, pp 570

Heip CHR, Goosen NK, Herman PMJ, Kromkamp J, Middelburg JJ, Soetaerd K (1995) Production and consumption of biological particles in temperate tidal estuaries. Ocean Mar Biol Annu Rev 33:1-149

Helder W (1974) The cycle of dissolved inorganic nitrogen compounds in the Wadden Sea. Neth J Sea Res 8:154-173

Hydes DJ, Kelly-Gerreyn BA, Le Gall AC, Proctor R (1999) The balance of supply of nutrients and demands of biological production and denitrification in a temperate latitude shelf sea-a treatment of the southern North Sea as an extended estuary. Mar Chem 68:117-131

Joint I, Pomroy A (1993) Phytoplankton biomass and production in the southern North Sea. Mar Ecol Prog Ser 99:169-182

Laane RWPM (1992) Background concentrations of natural compounds. Report DGW-92.033, Den Haag (NL), pp 84

Lenhart H-J (1999) Eutrophierung im kontinentalen Küstenbereich der Nordsee. Berichte aus dem Zentrum für Meeres - und Klimaforschung. reihe B: Ozeanographie, No. 35, pp 169

Lenhart H-J, Pätsch J (2001) Daily nutrient loads of the European continental rivers for the years 1977-1998. Berichte aus dem Zentrum für Meeres - und Klimaforschung; Reihe B: Ozeanographie, No. 40, $146 \mathrm{pp}$

Nixon SW (1990) Marine eutrophication: a growing international problem Ambio 19:101

Nixon SW (1995) Coastal marine eutrophication: a definition, social causes, and future concerns. Ophelia 41:199-219

Pasternack GB, Brush GS, Hilgartner WB (2001) Impact of historic land-use change on sediment delivery to a Chesapeake Bay subestuarine delta. Earth Surf Process Landforms 26:409427

Postma H (1954) Hydrography of the Dutch Wadden Sea. Arch néerl Zool 10:405-511

Postma H (1966) The cycle of nitrogen in the Wadden Sea and adjacent areas. Neth J Sea Res 3:186-221

Reise K (1994) Changing life under the tides of the Wadden Sea during the 20th Century. Ophelia Suppl 6:117-125

Reise K (2005) Coast of change: habitat loss and transformations in the Wadden Sea. Helgol Mar Res 58: (in press)

Reise K, Siebert I (1994) Mass occurrence of green algae in the German Wadden Sea. D Hdyr Zeit Suppl 1:171-188

Smith SV, Hollibaugh JT (1993) Coastal metabolism and the oceanic carbon balance. Rev Geophys 31:75-89

Syvitski JPM (2003) Supply and flux of sediment along hydrological pathways: research for the 21st century. Global Planet Change 39:1-11

van Bennekom AJ, Wetsteijn FJ (1990) The winter distribution of nutrients in the southern bight of the North Sea (1961-1978) and in the estuaries of the Scheldt and the Rhine/Meuse. Neth J Sea Res 25:75-87

van Beusekom JEE, Diel-Christiansen S (1994) A synthesis of phyto- and zooplankton dynamics in the North Sea environment. WWF, Godalming, UK

van Beusekom JEE, de Jonge VN (1998) Retention of phosphorus and nitrogen in the Ems estuary. Estuaries 21:527-539

van Beusekom JEE, Brockmann UH, Hesse K-J, Hickel W, Poremba K, Tillmann U (1999) The importance of sediments in 
the transformation and turnover of nutrients and organic matter in the Wadden Sea and German Bight. Germ $\mathbf{J}$ Hydr 51:245-266

van Beusekom JEE, Fock $\mathrm{H}$, de Jong $\mathrm{F}$, Diel-Christiansen $\mathrm{S}$, Christiansen B (2001) Wadden Sea specific eutrophication criteria. Wadden Sea Ecosystem 14, Wilhelmshaven (Germany), $115 \mathrm{pp}$

van Beusekom JEE, de Jonge VN (2002) Long-term changes in Wadden Sea nutrient cycles: importance of organic matter import from the North Sea. Hydrobiologia 475/476:185-194

van den Hoek C, Admiraal A, Colijn F, de Jonge VN (1979) The role of algae in the ecosystem of the Wadden Sea: a review. In:
Wolff WJ (ed) Report 3: Flora and vegetation of the Wadden Sea. pp 9-118

van Raaphorst W, de Jonge VN, Dijkhuizen D, Frederiks B (2000) Natural background concentrations of phosphorus and nitrogen in the Dutch Wadden Sea. National Inst. Coastal Mar. Management, Report RIKZ/2000.013, pp 53

van Raaphorst W, de Jonge VN (2004) Reconstruction of the total $\mathrm{N}$ and $\mathrm{P}$ inputs from the IJsselmeer into the Western Wadden Sea between 1935-1998. J Sea Res 51:109-131

Zimmerman J (1976) Mixing and flushing of tidal embayments in the western Dutch Wadden Sea. Neth J Sea Res 10:149-191 